contract for the composition, electrotyping, printing and binding of the National Formulary ( $1 \mathrm{~V}$ ) to the J. B. Lippincott Company, of Philadelphia, was approved, and the Committee on Publication was empowered to make the necessary contract as soon as possible.

On motion of Philip Asher, seconded by F. M. Apple, the Committee on Publication was authorized to secure bids and make the necessary contract for the business agency and sale of the National Formulary, Fourth Edition.

The election for officers for the ensuing year was then held, the following being chosen :

General Secretary-William B. Day.

Treasurer-Henry M. Whelpley.

Reporter on the Progress of Pharmacy-C. Lewis Diehl.

Historian-Eugene G. Eberle.

The selection of a Local Secretary was referred to the Council of 1914-15.

Adjourned until Saturday, August 29, 1914.

J. W. England, Secretary.

\title{
(SEVENTH SESSION OF THE COUNCIL FOR 1913-1914.)
}

The seventh session of the Council was held on Saturday, August 29, 1914, at 9 a. m., Chairman Eberle presiding.

Present: Messrs. Craig, England, Fennel, Godding, Hopp, LaPierre, Mayo, Nitardy, Richardson, Ruddiman, Seltzer, Whelpley and Wulling.

The following resolutions were passed by the House of Delegates and referred to the Council :

1. That the House of Delegates endorse the aims and purposes of the Chicago Veteran Druggists Association and recommend the formation of similar associations as Sections of the Local Branches of the A. Ph. A., provided that the members of such Association shall be also members of the American Pharmaceutical Association.

Decision: Approved.

2. That the American Pharmaceutical Association instruct its representatives in the National Drug Trade Conference to act immediately in connection with the representatives of the allied branches of the drug trade in the Drug Trade Conference to draft at the earliest possible moment a bill to reform the present patent law, registration of names of drugs and the granting of sole right to sell certain drugs to the people of the United States suitable to the best interests of the drug trade in the United States, and to urge its passage at the earliest possible opportunity, and the support of the A. Ph. A. is hereby pledged to such reform.

Decision: Approved.

3. That the A. Ph. A. make all possible effort to have only graduates of recognized schools of pharmacy nominated as members of the State Boards of Pharmacy by the State Associations and where possible have such amendments made to state laws as will make such qualifications a prerequisite.

Decision: Approved.

4. That the incoming president be and is hereby instructed to appoint a committee of three members, which committee shall confer with similar committees, appointed for the same purpose by other organizations, upon the advisability of forming a congress of national drug and pharmaceutical bodies under the auspices of the American Pharmaceutical Association. And be it further Resolved, That the results of the conference of these committees shall be reported to the several organizations represented and to the American Pharmaceutical 
Association at their annual meetings in nineteen hundred and fifteen, with such recommendations as may be agreed upon.

Decision: Approved.

5. Whereas, The usefulness of the House of Delegates during its two years' existence, not having been such as was expected at the time of its installation, it is important that something be done to increase this usefulness; therefore, be it Resolved, That it is the sense of this House of Delegates that increased efficiency can be secured by making this body a permanent one instead of making its existence dependent upon the actions of the Council.

Decision: Referred to the Committee on House of Delegates appointed by the Council.

6. That it is the belief of the House of Delegates that the Year Book should contain abstracts of papers submitted by the members of the American Pharmaceutical Association and published in the Journal of the American Pharmaceutical Association.

Decision: Referred to the Committee on Publication with power to act.

7. That the President of the American Pharmaceutical Association, at the opening session of each annual convention, shall appoint an official censor whose duty it shall be to supervise matter given to representatives of the local press, and to insure that fair and accurate accounts of the proceedings and business of the Association during such meetings shall be fairly and accurately printed.

The subject of convention publicity received extended discussion.

F. J. Wulling moved, seconded by L. A. Seltzer, that the publicity work of the Association should be composed of two divisions: (1) preconvention work, (2) convention work.

(1) The preconvention work should be done by the Local Committee.

(2) The Convention work should be done by a committee composed of an Association Reporter, as Chairman, and the Chairmen of the several Sections of the Association and the General Secretary and Secretary of the Council as members who should report briefly in writing the proceedings and news of the several bodies to the Reporter, who should be the channel of communication to the press.

The motion was adopted.

8. That the principle in these two measures-the Metz Bill and the Stevens Bill, i. e., price standardization, be approved by this Association.

Decision: Adopted.

A vote on Motion No. 42 of Council Letter No. 27 on offer of Wm. S. Merrell Co., for assignment of patent rights for improved package for antiseptic poisons (which was an amendment of Motion No. 41 of Council Letter No. 26 on Assignment of Patent Rights for Improved Package for Antiseptic Poisons) was called for by J. A. Koch, seconded by C. A. Mayo, and the original motion was amended. and as a whole was adopted.

The following applications for membership were presented and favorably acted upon:

No. 432. Geo. E. Doyle, 1190 West Fort St., Detroit, Mich., rec. by Wm. A. Hall and $J$. W. England.

No. 433. Adelbert P. French, 2782 Woodward Ave., Highland Park, Mich., rec. by Wm. A. Hall and Leonard A. Seltzer.

On:motion of $\mathrm{H}$. M. Whelpley, seconded by J. A. Koch, the traveling expenses of the Secretary of the Council for this meeting were directed to be paid. The expenditure met with the approval of the Committee on Finance: 
On motion of H. M. Whelpley, seconded by J. W. England, it was agreed that the Rules of Finance be so amended that the Committee on Finance shall audit all bills before payment is made.

J. A. Koch moved, seconded by F. J. Wulling, that the Acting General Secretary be requested to confer with the General Secretary elect, and arrange for the transfer of the property of the Association belonging to the secretarial office as soon as possible, and that the salary of the General Secretary elect be seven hundred and fifty dollars per annum and date as of September 1, 1914 . .

Adjourned.

J. W. England, Secretary.

\section{(FIRST SESSION OF THE COUNCIL FOR 1914-15.)}

Immediately after the adjournment of the seventh session of the Council for 1913-1914, the first or organization meeting of the Council for 1914-15 was held on Saturday, August 29, 1914, at 10 a. m.

Chairman Eberle presided as Acting Chairman.

Present: Messrs. Whelpley, Wilbert, Eberle, Godding, Day, Shafer, Wulling, England, Hopp, Osseward and Mayo.

The following officials were elected:

Chairman-E. G. Eberle.

Vice Chairman-John G. Godding.

Secretary-J. W. England.

The Chairman and Secretary of the Council were named as the Committee on Nomination of Council Committees for 1914-15 to report to the Council later.

Adjourned.

J. W. England, Secretary.

PROCEEDINGS OF THE HOUSE OF DELEGATES OF THE AMERICAN PHARMACEUTICAL ASSOCIATION.

Sixty-second Annual Meeting, Detroit, Michigan, August 24th to 28th, 1914.

(First Session.)

The first session of the House of Delegates was called to order August 24th, at 8 o'clock p. m. in room " $\mathrm{C}$ " of the Convention Hall of the Hotel Pontchartrain.

The meeting was called to order by Chairman Clyde M. Snow, of Chicago.

The Chairman stated that the first order of business was the calling of the roll of delegates whose credentials had been approved by the Council, but that unfortunately the Council up to that time had not presented the roll of delegates whose credentials had been approved.

Chairman Snow stated he had discussed in a general way with some of the members the measures it would be best to adopt in the House of Delegates, and it seemed to be the opinion of the delegates in the room, at least, that the meeting proceed with the order of business so far as it can. It had been suggested that the Committee on Resolutions will have but little time to consider proposed resolutions, and it seemed well that the meeting should at least appoint a Committee on Resolutions and receive as many of them as possible from the members present. 